\title{
Properties and Comparative Starch-gel Electrophoresis of Megacins from Several Bacillus megaterium Strains
}

\author{
BY HELEN D. DONOGHUE \\ Department of Bacteriology, The Medical School, \\ University Walk, Bristol, BS8 ITD \\ (Received 7 February 1972; revised 3 May 1972) \\ SUMM A RY
}

The products of several megacinogenic strains of Bacillus megaterium were analysed by starch-gel electrophoresis. All were mixtures of inhibitors, among which megacins A, C and Cx could be distinguished. Several non-inducible megacins were produced in liquid medium and they seemed to be a heterogeneous group which may correspond to 'megacin B'. The effects of heat and proteolytic enzymes on megacins were investigated and the molecular weights of several megacins were estimated by chromatography using Sephadex G 200. The molecular weight of crude megacin $C$ was about 153000 . Strains producing megacins $C$ and $\mathrm{Cx}$ could be 'cured' by growth at $43{ }^{\circ} \mathrm{C}$. Megacins $\mathrm{C}$ and $\mathrm{Cx}$ were released from the surface of $\mathrm{meg}^{+}$organisms by partial digestion of the wall with trypsin or lysozyme.

\section{INTRODUCTION}

Megacins, bacteriocins produced by Bacillus megaterium, appear to be a rather heterogeneous group. First discovered by Ivanovics \& Alföldi (I954), they were provisionally classified into three groups by Holland \& Roberts (1964) using the criteria of production characteristics, spectrum of activity and mode of action. Megacin A was defined as being inducible, having a very wide spectrum of activity, and acting on the cytoplasmic membrane of sensitive organisms to cause lysis. Megacin A is now known to be a phospholipase $\mathrm{A}_{2}$ (Ozaki et al. 1966; Ochi et al. I97I). Megacin B was characterized by a narrower spectrum of activity, being non-inducible and by being produced only on solid medium. Megacin $\mathrm{C}$ had a very narrow spectrum of activity and was produced by uninduced cultures in the late exponential phase. The megacin produced by B. megaterium 337 (Durner \& Mach, 1966) was provisionally called megacin $\mathrm{Cx}$, as the characteristics of its production were similar to megacin C. This megacin has been purified by Durner (1970a) and its mode of action differs from that of crude megacin C (Durner, I970 $b$; Holland, 1965).

Preliminary experiments showed that megacins could easily be distinguished by starchgel electrophoresis. It is a very gentle procedure, which is necessary as many megacins are unstable. Since starch-gel is non-toxic, the position of megacins can be shown by inhibition zones in an overlying sensitive strain, which is a method far more sensitive and specific than using stains.

\section{METHODS}

Organisms. Bacillus megaterium strains $2 \mathrm{I} 6\left(\mathrm{megA}^{+} \mathrm{C}^{+}\right), 2 \mathrm{I6 \textrm {A } ^ { - }}\left(\mathrm{megA}^{-} \mathrm{C}^{+}\right)$and 337 $\left(\mathrm{megCx}{ }^{+}\right.$) were obtained from Professor G. Ivanovics, Institute of Microbiology, University Medical School, Szeged, Hungary. Bacillus megaterium $\mathrm{C}_{4 \mathrm{~A}^{-}}\left(\mathrm{megA} \mathrm{C}^{+}\right)$was obtained from Dr I. B. Holland, Department of Genetics, Leicester, England. Strain 2I6(3I) is a 
non-inducible mutant isolated from $B$. megaterium 2 I6. Strains $\mathrm{C}_{4}-$ and $337-$ are megCand megCx $\mathrm{X}^{-}$respectively. The departmental strains $\mathrm{BI}, \mathrm{B} 2$ and $\mathrm{B} 4$ are non-inducible megacin producers. Other strains were obtained from soil samples according to the method of Holland \& Roberts (1964). Strain 192 is an inducible meg $^{+}$strain and 34 is a non-inducible meg $^{+}$strain. Bacillus megaterium $\mathrm{I} 62 \mathrm{u}$ is a streptomycin-resistant indicator strain which is far more sensitive to megacins than all other strains tested.

Media. Oxoid blood agar base no. $2(4 \%, w / v$; NA) was used for routine subculture of strains at $37{ }^{\circ} \mathrm{C}$. Peptone water (PW) was the routine liquid medium containing $\mathrm{I} \%(\mathrm{w} / \mathrm{v})$ each of bacto-peptone and bacto-tryptone, and $0.05 \%$ (w/v) $\mathrm{NaCl}$. Soft agar used for overlayering plates contained Difco nutrient broth $\mathrm{I} \cdot 6 \%(\mathrm{w} / \mathrm{v}), \mathrm{NaCl} 0.5 \%(\mathrm{w} / \mathrm{v})$ and bacto agar $0.7 \%(\mathrm{w} / \mathrm{v})$.

Peptone glucose broth (PGB) (Holland, I96I) was used for megacin production. The PRE medium of Cundliffe (I968) containing $10 \%(\mathrm{w} / \mathrm{v})$ sucrose and $0 . \mathrm{I} \%(\mathrm{w} / \mathrm{v})$ peptone was used for cultures before their conversion to protoplasts and for their subsequent incubation as protoplasts.

Buffers. Discontinuous buffers for starch-gel electrophoresis were tris-citrate buffer, pH 8.60 to 8.65 (gel), and borate buffer, pH 8.60 to 8.65 (bridge solution) (Poulick, I957). Phosphate buffer was equal volumes of o. I M- $\mathrm{KH}_{2} \mathrm{PO}_{4}$ and $\mathrm{O} \cdot \mathrm{I} \mathrm{M}-\mathrm{K}_{2} \mathrm{HPO}_{4}$, pH adjusted to $7 \cdot 20$ with $\mathrm{NaOH}$. Barbitone buffer was prepared from stock solution $\mathrm{A}, 0.2 \mathrm{M}$-sodium barbitone (sodium diethyl barbiturate) and stock solution $\mathrm{B}, 0.2 \mathrm{M}-\mathrm{HCl}$; $(50 \mathrm{ml} \mathrm{A}+9 \mathrm{ml}$ $\mathrm{B}+\mathrm{I} 4 \mathrm{ml}$ water to give $\mathrm{pH} 8 \cdot 40$ ).

Chemicals. Lysozyme from hen egg, A grade, was purchased from Calbiochem Ltd, London, WIH IAS; hydrolysed starch from Connaught Medical Research Laboratories, Toronto, Canada; streptomycin sylphate from Glaxo Laboratories Ltd, Greenford, Middlesex Blue Dextran and Sephadex (G 200 and G 25) from Pharmacia (G.B.) Ltd, London, W. 5 . Pure $\alpha$-chymotrypsin ex bovine pancreas, pure human $\gamma$-globulins Cohn fraction II, pure myoglobin from sperm whale, papain (twice crystallized), pure pepsin (from hog pancreas and tris puriss A.R. were obtained from Koch-Light Laboratories Ltd, Colnbrook, Buckinghamshire. Sigma Chemical Co., London supplied bovine serum albumin (fraction $\mathrm{V}$ and pure preparations), $\alpha$-chymotrypsinogen A type 2, crystalline mitomycin $\mathrm{C}$, ovalbumin A.R. Grade V (pure) and trypsin type III, pure.

Megacin production. Overnight PW cultures of the producer strain were inoculated into PGB so that they were diluted 25 -fold and incubated on a shaker in a $35^{\circ} \mathrm{C}$ water bath. Strain $2 \mathrm{I} 6$ was induced to produce megacin $A$ by adding mitomycin $C(0.2 \mu \mathrm{g} / \mathrm{ml})$ to a culture in the early exponential phase of growth. On re-incubation, the megacin was released by lysis approximately $2 \mathrm{~h}$ later.

Megacins $\mathrm{C}$ and $\mathrm{Cx}$ were harvested when the culture of the producing organism was in late exponential phase and all other megacins, including those produced by uninduced $\mathrm{megA}^{+}$strains, were harvested when the cultures were in the stationary phase. The bacteria were centrifuged at $10000 \mathrm{~g}$ for $30 \mathrm{~min}$ at $5{ }^{\circ} \mathrm{C}$ and bovine serum albumin $(\mathrm{I} \mathrm{mg} / \mathrm{ml}$ ) was dissolved in the supernatant liquid (Mitusi \& Mizuno, 1969). The preparation was dialysed overnight at $5{ }^{\circ} \mathrm{C}$ against $\mathrm{I} \cdot \mathrm{O} \mathrm{mM}$-phosphate buffer, $\mathrm{pH} 7 \cdot 2 \mathrm{O}$. The megacins were then shaken with chloroform to reduce contamination and freeze-dried.

The freeze-dried megacins were prepared for use by making a saturated solution in sterile distilled water. Occasionally freshly prepared crude supernatant liquids from cultures were used instead of freeze-dried preparations.

Megacin assay. A spot method similar to that of Ivanovics \& Alföldi (1955) was used. Plates of NA containing streptomycin ( $10 \mu \mathrm{g} / \mathrm{ml}$ ) were overlayered with $4 \mathrm{ml}$ of soft agar 
containing $0.1 \mathrm{ml}$ of an overnight PW culture of the indicator strain $\mathrm{I} 62 \mathrm{u}$. The megacin preparations were diluted in saline and spotted on to the seeded agar surface using a standard loop. The reciprocal of the highest dilution giving detectable clearing of the indicator was taken as the megacin titre in arbitrary units/ml. Induced preparations contained $\mathrm{I} \times 1 \mathrm{IO}^{4}$ to $\mathrm{I} \times 1 \mathrm{IO}^{8}$ arbitrary units $/ \mathrm{mg}$ protein. Freshly prepared uninduced megacins had titres from $0 \cdot 1$ to Io arbitrary units $/ \mathrm{mg}$ protein.

Lysozyme treatment and preparation of protoplasts. The method of Cundliffe (1968) was used with minor modifications. Organisms in the exponential phase were treated with lysozyme $(500 \mu \mathrm{g} / \mathrm{ml})$ in PRE medium at $37^{\circ} \mathrm{C}$ until they were seen by phase-contrast microscopy to have been converted into protoplasts. The protoplasts were diluted 20 -fold with fresh medium and incubated at $37^{\circ} \mathrm{C}$ for about $\mathrm{I} 8 \mathrm{~h}$ while gently shaking.

When the supernatant liquids after lysozyme treatment were to be tested for megacin activity, the bacteria were washed thoroughly in warm PRE medium before lysozyme treatment. After protoplast formation the preparation was centrifuged and the supernatant liquid removed.

Starch-gel electrophoresis. The method was essentially that of Smithies (1955), with the discontinuous buffer system of Poulick (1957). During the experiments air was excluded from the gel by a 'terphane' polyester film (BCL Plastic Films Division, British Cellophane Ltd, Regal House, Twickenham, Middlesex). Samples were inserted into the gel on Whatman no. $3 \mathrm{~mm}$ filter-paper strips that had been blotted. The samples were placed near the cathode and a potential of $\mathrm{I} V / \mathrm{mm}$ gel was used. Megacin from induced $2 \mathrm{I} 6$ was usually included in each run to provide an internal standard. Runs were continued for 5 to $6 \mathrm{~h}$ until the buffer line had almost travelled to the anode, about $105 \mathrm{~mm}$ from the cathode. The gel was then sliced into horizontal layers which were placed in flat dishes and each overlayered with NA seeded usually with $\mathrm{I} .5 \mathrm{ml}$ of overnight PW culture of an indicator strain per $\mathrm{I} 5$ to $20 \mathrm{ml}$ of soft agar held at $55^{\circ} \mathrm{C}$. After overnight incubation at $37^{\circ} \mathrm{C}$ the slices were examined for inhibition zones by placing them against a dark background with oblique lighting. The positions of the zones were carefully measured and drawn on accurate full-scale plans. Four slices from each run were overlayered with different indicator strains or were used as replicates.

Heat-treatment of megacins. Megacin solutions were held for $\mathrm{I} h$ in a water bath at $60{ }^{\circ} \mathrm{C}$. A control solution of the same megacin was held for $\mathrm{I} h$ at $37^{\circ} \mathrm{C}$.

Treatment of megacins with proteolytic enzymes. Trypsin and chymotrypsin (each I mg/ml) were dissolved in $0.04 \mathrm{M}$-barbitol buffer, $\mathrm{pH} 8.0$. Pepsin $(\mathrm{I} \mathrm{mg} / \mathrm{ml})$ was dissolved in $0 . \mathrm{I}$ Mglycylglycine buffer, $\mathrm{pH} 2 \cdot 8$ to $2 \cdot 9$. Undiluted papain suspension $(0.3 \mathrm{ml})$ was mixed with $5 \mathrm{ml}$ of $\mathrm{O} . \mathrm{I} \mathrm{M}$-sodium acetate, $\mathrm{pH} 4.5$, containing $0.0 \mathrm{I}$ M-cysteine and 0.0I M-EDTA (Kemmel \& Smith, I954). Equal volumes of megacin and each enzyme solution were mixed and left at $37^{\circ} \mathrm{C}$ for $\mathrm{I}$ h. As a control, buffer alone was added to the megacin.

Molecular weight estimation. A Pharmacia column (internal diameter $25 \mathrm{~mm}$ ) was packed with Sephadex G 200 to a depth of approximately $40 \mathrm{~cm}$. A thin layer of Sephadex G 25 was added to the top of the column to prevent damage to the bed during the addition of samples. Phosphate buffer, $\mathrm{O} \cdot 0 \mathrm{I} \mathrm{M,} \mathrm{pH} 7 \cdot 2$, was used at $2{ }^{\circ} \mathrm{C}$ and a fraction collector and Uvicord (LKB-Produkter AB, Sweden) were connected. At the start of every run a $2 \%(\mathrm{w} / \mathrm{v})$ Blue Dextran solution (I to $2 \mathrm{ml}$ ) was added to estimate the void volume $\left(V_{0}\right)$. Each sample was made of high density by saturating with sucrose. The standard curve was constructed with $\gamma$-globulin, bovine serum albumin, ovalbumin, $\alpha$-chymotrypsinogen and myoglobin (Andrews, 1964). During standardization of the column, ro to $15 \mathrm{mg}$ of each standard was dissolved in the Blue Dextran solution and up to three standards were used 


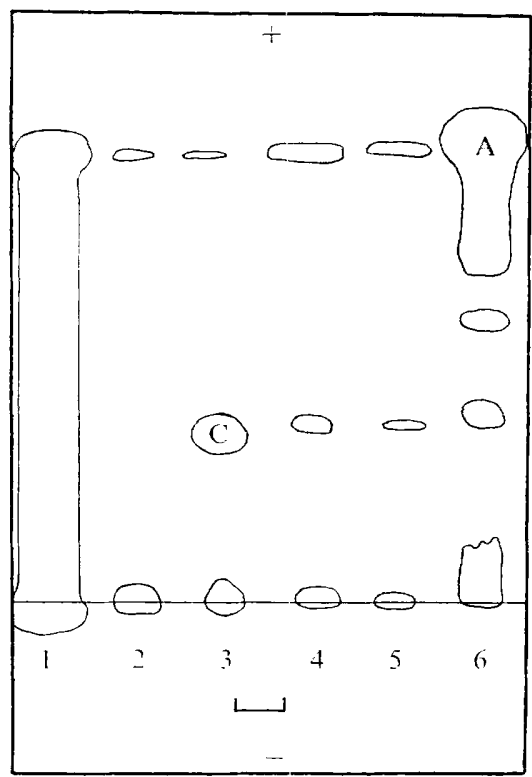

Fig. I

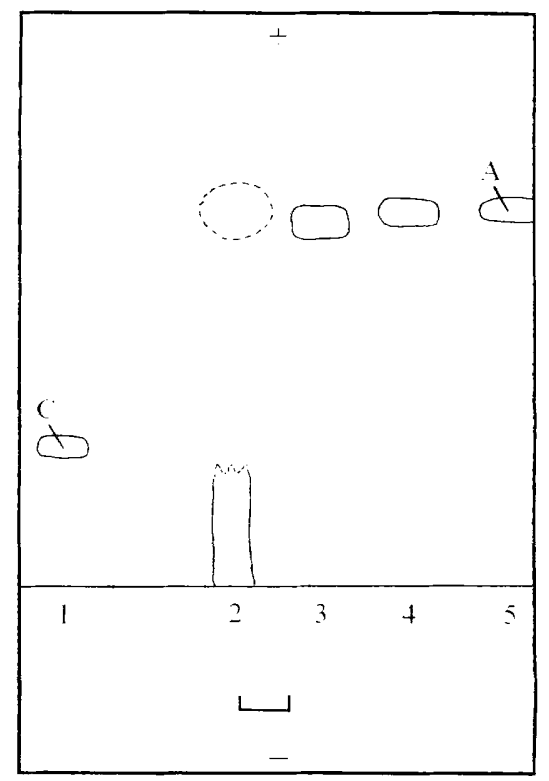

Fig. 2

Fig. I. Starch-gel electrophoresis of megacins. The producing stains were: induced 192 (I), I92 (2), $\mathrm{C}_{4 \mathrm{~A}^{-}}$(3), $2 \mathrm{I} 6$ (3I) (4), $2 \mathrm{I} 6$ (5) and induced $2 \mathrm{I} 6$ (6). The positions of the megacins (freshly are shown by the prepared zones of inhibition of the indicator strain $162 \mathrm{u}$. The bar represents $\mathrm{I} \mathrm{cm}$.

$$
\mathrm{A}=\text { megacin } \mathrm{A} ; \mathrm{C}=\text { megacin } \mathrm{C} \text {. }
$$

Fig. 2. Starch-gel electrophoresis of megacins. The plan shows the megacin from $\mathrm{C}_{4 \mathrm{~A}^{-}}$(I) and the effect of treatment with heat (2), chymotrypsin (3) and trypsin (4) on megacin from induced 216 , compared with the untreated control preparation (5). The indicator strain is I62u. The bar represents $\mathrm{I} \mathrm{cm}$.

$$
\mathrm{A}=\text { megacin } \mathrm{A} ; \mathrm{C}=\text { megacin } \mathrm{C} \text {. }
$$

per run. Megacin preparations were usually in the form of a freeze-dried powder and as much as possible was dissolved in the I to $2 \mathrm{ml}$ of the Blue Dextran solution. The fractions were collected and assayed for megacin activity. The results, in arbitrary units $/ \mathrm{ml}$, were plotted on to the Uvicord graph and the elution of the peak of the activity determined $\left(V_{t}\right)$ and hence the $V_{t} / V_{0}$ ratio. From the standard curve, of $V_{t} / V_{0}$ against log molecular weight, the molecular weight of the sample was calculated.

\section{Preliminary electrophoretic studies}

\section{RESULTS}

Freshly prepared megacins gave several distinct inhibition zones and one of these was immobile (Fig. I). In older or freeze-dried preparations, only the major components of each preparation were visible. The inhibition zones were assumed to be caused by megacins. They were not found in preparations from meg- strains. Zones caused by bacteriophage would be immobile and increase in size during incubation; this was never seen.

The most mobile zone (mobility approximately $\mathrm{I} 5 \mathrm{~mm} / \mathrm{h}$ ) probably corresponds to megacin A. Little was present in preparations from 2I6(3I) or uninduced I92 or 216, yet there was a huge increase in this component in induced 192 or 216 cultures. The major component produced by $\mathrm{C}_{4} \mathrm{~A}^{-}$is assumed to be megacin $\mathrm{C}$. If so, both 216 and $2 \mathrm{I} 6(3 \mathrm{I})$ produce small amounts of megacin $\mathrm{C}$ because a zone of identical mobility is seen when their 
Table I. The composition of different megacin preparations shown by starch-gel electrophoresis

The positions of megacins were recognized by the zones of inhibition of the indicator organism (Bacillus megaterium $\mathrm{I} 62 \mathrm{u})$.

\begin{tabular}{|c|c|c|c|c|c|c|c|c|}
\hline & & expres & as ave & $\begin{array}{l}\text { mpon } \\
\text { d frac }\end{array}$ & $\begin{array}{l}\text { prese } \\
\text { of } \mathrm{mo}\end{array}$ & $y$ of $n$ & in A) & \\
\hline & & & & & & & & \\
\hline & & & $\overparen{C x}$ & $\widehat{C}$ & & & & $\begin{array}{c}\text { Megacin } \\
\text { A }\end{array}$ \\
\hline $\mathrm{Meg}^{+}$strains & Immobile & 0.05 & $0 \cdot 10$ & 0.39 & $0.6 \mathrm{I}$ & 0.74 & 0.83 & I $\cdot 00$ \\
\hline I92 (induced) & + & & & Unr & ed int & & & + \\
\hline 192 & + & - & - & - & - & - & - & + \\
\hline 216 (induced) & + & - & - & + & + & + & + & + \\
\hline 216 & + & - & - & + & - & - & - & + \\
\hline $216(31)$ & + & - & - & + & - & - & - & + \\
\hline ' $216 A^{-}$' & + & - & - & - & - & - & - & + \\
\hline $\mathrm{C} 4 \mathrm{~A}^{-}$ & + & - & - & + & - & - & - & + \\
\hline 337 & - & - & + & - & - & - & - & - \\
\hline BI & - & + & - & - & - & - & - & - \\
\hline B2 & - & - & - & - & - & - & - & + \\
\hline 34 & + & - & - & - & - & - & - & - \\
\hline
\end{tabular}

products are electrophoresed (Fig. I). Strain ' $216 \mathrm{~A}^{-}$', described as being a mutant producing only megacin $\mathrm{C}$ and not megacin $\mathrm{A}$ (G. Ivanovics, personal communication), appears in other experiments to be similar to $216(3 \mathrm{I})$, but a megacin $\mathrm{C}$ zone has never been demonstrated in its supernatant liquid. Strain $\mathrm{C}_{4} \mathrm{~A}^{-}$is apparently an uninducible mutant like 2I6(3I), but produces a large proportion of megacin $C$ and a very small proportion of megacin $\mathrm{A}$ and the immobile component. The position of the megacin $\mathrm{C}$ inhibition zone was confirmed, using $\mathrm{C}_{4} \mathrm{~A}^{-}\left(\mathrm{megC}^{+}\right)$and the negative mutant, $\mathrm{C} 4-$, as indicators. The zone was visible only when using strain $\mathrm{C}_{4}-$ as the indicator. The megacin $\mathrm{C}$-producing strain, $\mathrm{C}_{4 \mathrm{~A}^{-}}$, is sensitive only to very high concentrations of megacin $\mathrm{C}$. Megacin $\mathrm{Cx}$, produced by strain 337, could be distinguished by a distinct zone which moved only a short distance from the cathode (Fig. 4). This was confirmed by using both strain 337 and the megC- mutant, strain $337^{-}$, as indicators. A zone of inhibition was visible only when the negative mutant was used. Other megacins were much weaker, and some appeared immobile under the conditions of the experiment so that they could not be distinguished from each other. Generally only strain $\mathrm{I} 62 \mathrm{u}$, the most sensitive indicator strain, was inhibited by them. The preparation from induced 192 may contain other components but these cannot be resolved as the indicator strain is inhibited over the whole area of gel between the base-line and the very mobile component. Megacin from induced 2 I 6 contains additional weak components found in fresh preparations, presumably released by lysis (Table I).

\section{Megacin A}

Both strains 192 and 216 were inducible and both produced a megacin with the same electrophoretic mobility. These two megacins differed, however, in their susceptibility to heat and proteolytic enzymes. Megacin from induced 192 was very heat-sensitive and was inactivated by trypsin treatment. Neither trypsin nor chymotrypsin had any observable effect on megacin from induced 2r6 (Fig. 2). However, trypsin treatment decreased the amount of clearing on plates of the indicator although the titre appeared the same. The 


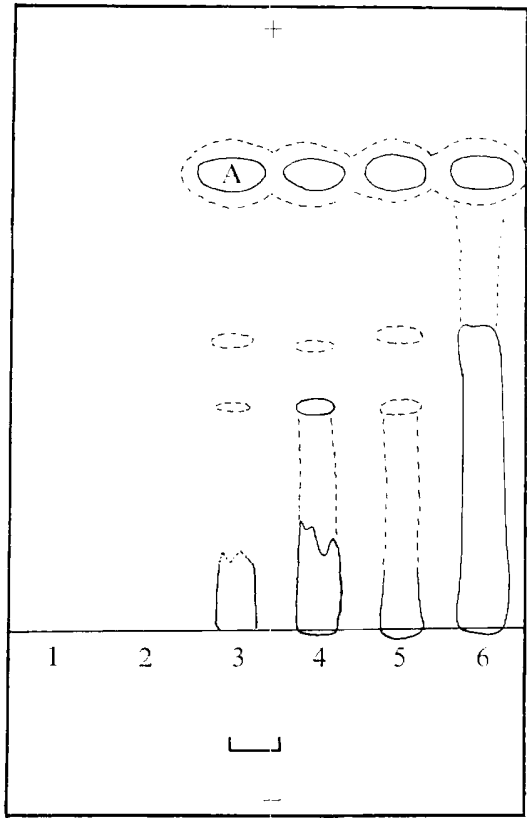

Fig. 3

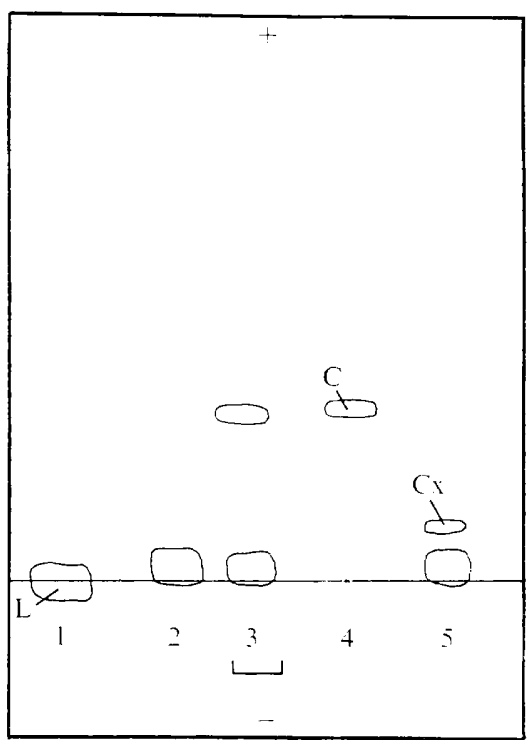

Fig. 4

Fig. 3. Starch-gel electrophoresis of megacin from induced Bacillus megaterium 216. Organisms were harvested at $\mathrm{I} \frac{1}{4} \mathrm{~h}(\mathrm{I}, 2), 2 \mathrm{~h}(3,4)$ and $3 \mathrm{~h}(5,6)$ after lysis. The earliest sample $(\mathrm{I}, 2)$ shows no activity. Preparations 2,4 and 6 were heat-treated, and preparations I, 3 and 5 are the untreated controls. The indicator is $162 \mathrm{u}$. The bar represents $\mathrm{I} \mathrm{cm}$.

$$
\mathrm{A}=\text { megacin A. }
$$

Fig. 4. Starch-gel electrophoresis of the products of lysozyme treatment of Bacillus megaterium. Lysozyme solution ( $15 \mathrm{mg} / \mathrm{ml}$ ) (I); the supernatant liquid obtained by treating washed $\mathrm{C} 4-$ (2) and $\mathrm{C}_{4} \mathrm{~A}^{-}$(3) organisms with lysozyme in PRE medium; supernatant liquid from strain $\mathrm{C}_{4} \mathrm{~A}^{-}$ growing in PRE medium (4); and the supernatant liquid obtained by treating washed 337 organisms with lysozyme in PRE medium (5). The indicator is $\mathrm{I} 62 \mathrm{u}$. The bar represents $\mathrm{I} \mathrm{cm}$.

$$
\mathrm{C}=\text { megacin } \mathrm{C} ; \mathrm{Cx}=\text { megacin } \mathrm{Cx} ; \mathrm{L}=\text { lysozyme. }
$$

molecular weights of the two megacins are different. That of the megacin from strain 192 was estimated to be about 68000 whereas megacin from strain 216 has a molecular weight of 51000 (Holland, 196I). However, megacin A preparations from different sources may have identical modes of action, although having slightly different physical properties (Nagy, Alföldi \& Ivanovics, 1959).

The effect of heat treatment on induced megacin from strain 216 is shown in Fig. 2. The mobile component is apparently converted into a less mobile component on heating. There is some evidence from agar-gel electrophoresis (Seed, 1970) that the less mobile component is converted into the mobile component on prolonged incubation of the induced culture. Prolonged incubation of the lysed induced culture definitely increases the proportion of the mobile component converted to the less mobile component which occurs on heating (Fig. 3).

Because megacins $\mathrm{C}$ and $\mathrm{Cx}$ may be wall components (see below), the production of megacin A by protoplasts was investigated. Protoplasts of strain 192 produced both mobile and immobile components in amounts comparable to those in supernatant liquids from uninduced cultures. This demonstrates that megacin A production did not depend on the presence of a bacterial wall. 
Properties of megacins
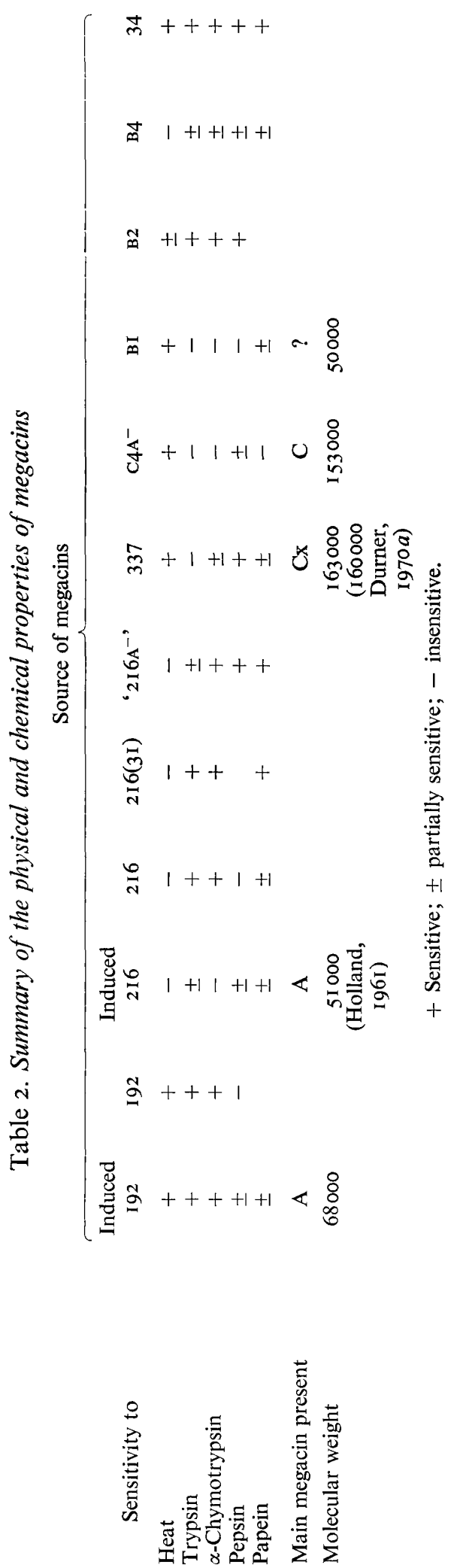


\section{Megacin B}

The megacins produced by many strains in the stationary phase of growth are assumed to be megacin B. The harvesting time is critical for detecting these megacins, which may be the reason why other workers have not obtained non-inducible megacins other than $\mathrm{C}$ and $\mathrm{Cx}$ in liquid medium. The molecular weight of one such megacin (from strain $\mathrm{BI}$ ) was about 50000 , which is comparable to that of megacin A. This group of megacins are heterogeneous and differ in their sensitivities to heat and proteolytic enzymes (Table 2).

\section{Megacins $C$ and $C x$}

These megacins are considered together as they have many properties in common, in spite of their different modes of action. Their distinct electrophoretic mobilities may be due to the differences in their molecular weights (Table 2).

Both strains $\mathrm{C}_{4} \mathrm{~A}^{-}$and 337 appeared to lose the meg+ character rather easily, and this loss was examined further by replica plating. High numbers of meg- clones could always be isolated from meg ${ }^{+}$cultures of both producer strains, and there was almost $100 \%$ conversion of $\mathrm{meg}^{+}$cultures to $\mathrm{meg}^{-}$when $\mathrm{meg}^{+}$cultures were grown in $\mathrm{PW}$ overnight at $43^{\circ} \mathrm{C}$, then spread on NA and incubated and replicated on to an indicator at $37^{\circ} \mathrm{C}$. Conversion of $\mathrm{meg}^{+}$to $\mathrm{meg}^{-}$cultures by chemical agents has not yet been demonstrated. $\mathrm{Meg}^{-}$clones have never shown any reversion to the $\mathrm{meg}^{+}$state. Many mixed clones, containing $\mathrm{meg}^{+}$and $\mathrm{meg}^{-}$organisms, were isolated during the investigation.

Holland \& Roberts (r964) have suggested that megacin C may be a wall component which is in equilibrium between bound and free states. Protoplasts, therefore, would not be expected to produce this megacin. This seems to be the case, as supernatant liquids from protoplasts of strain $\mathrm{C}_{4} \mathrm{~A}^{-}$contain all components except megacin $\mathrm{C}$. One reason for this may be that, although the protoplasts were prepared from cultures in the exponential phase of growth, the lysozyme treatment may have shocked the organisms, thus preventing megacin $\mathrm{C}$ synthesis and release. The protoplasts were shown to be metabolically active, however, by their reduction of triphenyl tetrazolium chloride (Tengerdy, Nagy \& Martin, 1967). Additional evidence that megacins $\mathrm{C}$ and $\mathrm{Cx}$ are wall-bound was given by electrophoresis of supernatant liquid obtained when washed $\mathrm{meg}^{+}$bacteria were treated with lysozyme. An inhibition zone due to the lysozyme was visible, and also a specific zone due to either megacin $\mathrm{C}$ or $\mathrm{Cx}$, depending on the producer strain used (Fig. 4). This was confirmed using the $\mathrm{meg}^{+}$and the meg- mutant strains as indicators. As also shown in Fig. 4, the meg $^{+}$organisms had already released megacin into the production medium before being converted into protoplasts. Thus the megacin released by lysozyme from the washed meg ${ }^{+}$organisms may have only adsorbed to the walls and not formed there. A similar result was obtained if bacteria grown in PGB medium were used, although such organisms are not converted into protoplasts by lysozyme. An attempt was made to dissociate the megacin from the meg $^{+}$wall by treatment with 8 M-lithium chloride (Pooley, Porres-Juan \& Shockman, 1970) but this was unsuccessful.

Megacins $\mathbf{C}$ and $\mathrm{Cx}$ were both trypsin-resistant, yet preliminary experiments of the 'trypsin-rescue' type (Reynolds \& Reeves, 1963) showed that immediate treatment of organisms that had adsorbed an excess of megacin led to partial rescue. This suggests that the megacin may be removed by digestion of its adsorption site on sensitive bacteria.

When washed $\mathrm{megC}^{+}$and megCx${ }^{+}$organisms (strains $\mathrm{C}_{4} \mathrm{~A}^{-}$and 337 ) were pretreated with trypsin and then washed again before the lysozyme treatment, electrophoresis of the lysozyme supernatant liquid showed a decrease in the amount of megacin released, com- 
pared to the controls that were not treated with trypsin. Hence, most of the megacin released by digestion of $\mathrm{meg}^{+}$walls is on the outer surface. There is no indication whether the remaining megacin is also on the outer surface or is on the inner surface, as would be the case if it were produced in the periplasmic space. When $\mathrm{meg}^{+}$organisms were grown in both PRE and PGB and treated with lysozyme with or without trypsin pretreatment, the washed suspensions of organisms had differing inhibitory activities. Those grown in PGB were more inhibitory to the indicator strain than those grown in PRE, and trypsin pretreatment increased the inhibition. The difference between the two media probably appears because lysozyme only partially digests the PGB-grown wall, so that less megacin is removed. The effect of the trypsin pretreatment may be to expose deeper layers of the wall to the lysozyme. The increased inhibitory activity of the remaining suspension suggests that there may be more megacin towards the inner wall surface.

\section{DISCUSSION}

The present work shows that there are at least three genes concerned with megacin production in strain 216: megacin A production, inducibility and megacin $\mathrm{C}$ production. According to Ochi et al. (1970), another associated product is that of the specific megacin A inhibitor. Strain 216 possesses all of these characteristics. Electrophoretic analysis has shown that strain $216(31)$ is a non-inducible mutant, though still producing megacins $A$ and $\mathrm{C}$. Strain ' $2 \mathrm{I} 6 \mathrm{~A}^{-}$' is also a non-inducible mutant, producing megacin A but apparently not megacin $\mathrm{C}$. The highly mobile megacin $\mathrm{A}$ component is shown by electrophoresis to be converted into a less mobile component on heating. The relationship between these two components is not yet understood. The megacin A inhibitor is reported to be reversible in action, trypsin-resistant and heat-sensitive (Ochi et al. 1970, 1971). The apparent conversion of the mobile into a less mobile component may be correlated in some way with the destruction of this megacin inhibitor. The weak megacins released in the stationary phase of growth of producer cultures may correspond to the group 'megacin B'. They are heterogeneous, although at least one has a molecular weight similar to that of megacin A. They may be released on autolysis as they are detected only at the end of the growth phase of meg ${ }^{+}$cultures.

Megacins $\mathrm{C}$ and $\mathrm{Cx}$ are both released from the walls of $\mathrm{meg}^{+}$organisms by lysozyme treatment and the trypsin-pretreatment experiment suggests that the megacins are on the outer wall surface. The site of production is not yet known but it must be inside the organism (although protoplasts do not produce,them) or in the periplasmic space. Megacins must somehow find their way through the wall, which is surprising in view of their high molecular weights. Isolated walls of Bacillus megaterium $\mathrm{KM}$ exclude uncharged molecules with a molecular weight greater than 57000 (Gerhardt \& Judge, 1964). However, there is extensive turnover of wall material in B. megaterium during the exponential phase (Chaloupka, Ř́íhová \& Křečková, I964). Megacins C and Cx may be released into the culture fluid at this time as a result of such turnover.

The rapid conversion of meg+ to $\mathrm{meg}^{-}$organisms which occurs at $43{ }^{\circ} \mathrm{C}$ suggests that possibly both the megC ${ }^{+}$and megCx ${ }^{+}$determinants may be on plasmids. It is not known, however, if such plasmids would be comparable to those in organisms such as Escherichia coli. Carlton \& Helinski (I969) obtained results suggesting that most of the DNA in both meg $^{+}$and meg- Bacillus megaterium strains is present as several covalently linked closed circles. They could not distinguish an additional DNA circle in $\mathrm{meg}^{+}$strains.

Megacins are obviously a very diverse group of inhibitory substances, as shown both 
by their molecular properties and their modes of action. Bradley (I967) has devised a classification system for bacteriocins which uses such characteristics as thermostability, molecular weight and sensitivity to proteolytic enzymes to distinguish bacteriocins derived from viruses or wall components. Megacins, however, cannot be fitted into this scheme. The activity spectra of megacins have already been used by the author to classify them by constructing a similarity matrix and performing a cluster analysis (Seed, 1970). This results in a grouping which is consistent with current information. An ideal classification scheme should also include all the known properties of megacins such as those discussed in this paper. At the present time this would give a more realistic picture of megacin classification than a scheme dependent on 'key' characters.

The author wishes to thank Dr Anna Mayr-Harting for her advice whilst the work was in progress and also during the preparation of this manuscript. Most of the work was carried out whilst the author was in receipt of an MRC Scholarship for training in research methods, and formed part of a Ph.D. thesis submitted to Bristol University.

\section{REFERENCES}

ANDrews, P. (1964). Estimation of the molecular weight of proteins by Sephadex gel-filtration. Biochemical Journal 91, 222-233.

BradLEy, D. E. (1967). Ultrastructure of bacteriophages and bacteriocins. Bacteriological Reviews 31, 230314.

Carlton, B. C. \& Helinski, D. R. (1969). Heterogeneous circular DNA elements in vegetative cultures of Bacillus megaterium. Proceedings of the National Academy of Sciences of the United States of America 64, 592-599.

Chaloupka, J., Říhová, L. \& K Ǩ̌EčKová, P. (1964). Degradation and turnover of bacterial cell wall mucopeptides in growing bacteria. Folia Microbiologica (Praha) 9, 9-15.

Cundliffe, E. (1968). Preparation and some properties of active protoplasts of Bacillus megaterium. Journal of General Microbiology 53, 425-430.

DURNER, K. (1970a). Anreicherung, Reinigung und Charakterisierung eines Bacteriocins aus Bacillus megaterium 337. Zeitschrift für allgemeine Mikrobiologie 1o, 93-102.

DURNER, K. (1970b). Untersuchungen zur Wirkungsweise von Megacin Cx auf Bacillus megaterium KM. Zeitschrift für allgemeine Mikrobiologie ro, 373-382.

Durner, K. \& MACH, F. (I966). Physiologische Untersuchungen eines Bacteriocins aus Bacillus megaterium 337. Zentralblatt für Bakteriologie, Parasitenkunde, Infectionskrankheiten und Hygiene (Abteilung I) 120, $565-575$.

Gerhardt, P. \& Judge, J. A. (1964). Porosity of isolated cell walls of Saccharomyces cerevisiae and Bacillus megaterium. Journal of Bacteriology 87, 945-95I.

Holland, I. B. (196I). The purification and properties of megacin, a bacteriocin from Bacillus megaterium. Biochemical Journal 78, 64I-648.

HollaNd, I. B. (I965). A bacteriocin specifically affecting DNA synthesis in Bacillus megaterium. Journal of Molecular Biology 12, 429-438.

Holland, I. B. \& Roberts, C. F. (1964). Properties of a new bacteriocin formed by Bacillus megaterium. Journal of General Microbiology 35, 27 I-285.

IVÁNovics, G. \& AlföLdi, L. (1954). A new antibacterial principle: megacine. Nature, London I74, 465.

IVÁNovics, G. \& AlFöldI, L. (1955). Observations on lysogenesis in B. megaterium and on megacine, the antibacterial principle of this Bacillus species. Acta microbiologica Academiae scientiarum hungaricae 2, 275-292.

Kemmel, J. R. \& Smith, E. L. (1954). Crystalline papain. I. Purification, specificity and activation. Journal of Biological Chemistry 207, 515-531.

Mitusi, E. \& Mizuno, D. (I969). Stabilisation of colicin E 2 by bovine serum albumin. Journal of Bacterio$\log y$ roo, II36-I 137 .

Nagy, D., Alföldi, L. \& Ivánovics, G. (1959). Megacins. Acta microbiologica Academiae scientiarum hungaricae 6, 327-336. 
Ochi, T., Yanagase, Y., Higashi, Y., Inoue, K. \& Amano, T. (1970). A specific inhibitor of megacin A from Bacillus megaterium producing megacin A. Biken Journal 13,63-76.

Ochi, T., Yano, K., Ozaki, M., Higashi, Y., Inoue, K. \& Amano, T. (1971). Studies on immunity to megacin A: susceptibility of phospholipids to phospholipase A activity of megacin A. Biken Journal I4, 29-36.

Ozaki, M., Higashi, Y., SaIto, H. O., AN, T. \& Amano, T. (I966). Identity of megacin A with phospholipase A. Biken Journal 9, $20 \mathrm{I}-2 \mathrm{I} 3$.

Pooley, H. M., Porres-Juan, J. M. \& Shockman, G. D. (1970). Dissociation of an autolytic enzyme-cell wall complex by treatment with unusually high concentrations of salt. Biochemical and Biophysical Research Communications, 28, I I 34-I I40.

Poulick, M. D. (1957). Starch gel electrophoresis in a discontinuous system of buffers. Nature, London $\mathbf{1 8 0}$ I $477-1479$.

ReYNolds, B. L. \& ReEVES, P. R. (I963). Some observations on the mode of action of Colicin F. Biochemical and Biophysical Research Communications II, I40-I45.

SEED, H. D. (1970). The Properties and Classification of Megacins Based on a Study of Selected Strains. Ph.D. Thesis, University of Bristol.

SMIthiEs, O. (1955). Zone electrophoresis in starch gels: group variations in the serum proteins of normal human adults. Biochemical Journal 6r, 629-64I.

Tengerdy, R. P., NAGY, J. G. \& MarTin, B. (1967). Quantitative measurement of bacterial growth by the

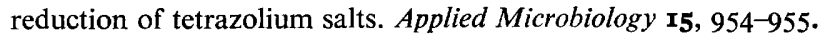

